\title{
Diversity, Abundance and Distribution of Birds In and Around Kakum National Park in Respect to Habitat Type
}

\author{
Mustapha Sumaila ${ }^{1}$, James Agyei-Ohemeng ${ }^{1 *}$, Obour Richard ${ }^{1}$, Asamoah Francis Boafo ${ }^{1}$, \\ Apraku William² \\ ${ }^{1}$ University of Energy and Natural Resources, Department of Ecotourism, Sunyani, Ghana \\ ${ }^{2}$ Ashanti African Tours, Jukwa, Ghana \\ Email: james.agyei-ohemeng@uenr.edu.gh
}

\begin{abstract}
Point count method was used to collect data on bird diversity, abundance and distribution in two habitats. 456 individual birds, from 60 families and 151 species were identified. The study indicated a significant difference in birds' abundance and species richness between the habitats. There was no significant difference between habitats and the feeding guild. The Mann Whitney U-test applied to test the difference in bird abundance between habitat types indicated that the number of birds in the Off-Reserve differed significantly from the On-Reserve as $\mathrm{p}<0.05$ ( $\mathrm{U}=$ $3578, \mathrm{p}=0.0001)$. whereas Shannon-Wiener diversity index $\left(\mathrm{H}^{\prime}\right)$ used to determine species diversity index was 3.950 and evenness of 0.927 . Sørensen's similarity, indicated that diversity of birds between the two habitat were not significant $(\mathrm{t}=0.099, \mathrm{df}=1$ and $\mathrm{P}=0.933$ at $\alpha=0.05)$. There was no significant difference in diversity between the On-Reserve and the Off-Reserve bird composition.
\end{abstract}

Keywords: point count method, off-reserve, on-reserve, settlement, livelihood, Kakum

\section{Introduction}

\subsection{General Introduction}

Ecotourism is often referred to as the lower impact form of tourism that takes local environment and people into consideration. The International Ecotourism Society defines ecotourism as "responsible travel to natural areas that conserves the environment, sustain the well-being of local people, and involves interpretation and education". For many countries ecotourism is not simply a marginal activity to finance protection of the environment, but major industry of the national economy. As people have become more educated and environmentally conscious in recent decades, the popularity of ecotourism has also risen [1].

Ideally, ecotourism creates a local incentive for conserving natural areas by generating income through operations that are sustainable, low-impact (environmental and social), low-investment, and locally owned [2]; [3]. Unfortunately, this ideal is rarely reached, in part due to what may be an inherent paradox: ecotourism aims to combine market-driven consumption of goods and services with sustainability [2]. In some cases, ecotourism actually creates new financial incentives for encroachment of natural areas through land speculation. In addition to that, the exclusion of local people from most of the benefits, leakage of profits out of the area, disturbance of wildlife, pollution, and even the outright habitat destruction that many 'ecotourism' operations cause [4]; [5], and it is easy to see why some consider ecotourism as another environmentally-destructive marketing device [6]; [3].

True ecotourism is preferable to alternative forms of economic development, such as logging, mining, or agriculture, because properly conducted ecotourism has the potential to protect natural areas and benefit local people at the same time [7]; [3].

One of the most promising activities of ecotourism which is being practice almost everywhere, as long as there is presence of avian wildlife, is Bird Watching. "Is the activity of observing birds either by naked eye or with the aid of vision enhancing equipment like binoculars and telescope for recreational purposes" [8]. Bird watching often involve a significant auditory component, as many bird species are more easily detected and identified by ear than the eye. The term "bird watching" appeared for the first time as the title of a book "Bird Watching" by Edmund Selous in 1901. Most birdwatchers pursue this 
activity for recreational or social reasons, unlike ornithologist, who engage in this study of birds using formal scientific methods. However, birdwatching is a recreational activity, and also being closely linked with conservation and preservation and often conveys a strong ethical and education component [7]. Since birders are highly motivated individuals, they sometimes travel and spend a considerable amount of money on bird watching. [8].

Thus, within the last 20 years, tourism operators have begun to understand and plan for bird watching, which has evolved the activity into a tourism niche [9]. [10] illustrated that bird-watching had a much greater following in the United States than previously thought. [10] illustrated again that birdwatching is planned and organized activity much like other forms of tourism. Moreover, [11] and [12] conducted a study and illustrated the positive economic impact that birding produced, the activity quickly gained recognition as a tourism niche.

Birdwatchers are one of the best sources of ecotourism income since they form the largest single group of Eco tourists, who are educated, have higher awareness of conservation issues and have above average incomes [13]. Because of the zeal of many birdwatchers and the resources these people are willing to invest in this activity, birdwatching is becoming the most rapidly growing and most environmentally conscious segment of ecotourism and provides economic hope for many threatened natural areas around the world [13]; [3].

According to [10], 300,000 American birdwatchers can be considered committed. These committed birdwatchers form the core group of international birding trip participants. Based on the 1994 American Birding Association membership survey [8], 49\% of committed birdwatchers travel out of the country for birdwatching. Of those, $32 \%$ have taken part in an organized bird tour. There are at least 127 companies that offer birdwatching tours worldwide (see, for example, Birding.com 2001), and considering that the average trip to a less developed country [8] from one of the largest six birding companies (over 150 birding tours per year) has 12 participants and costs over US\$ 4000 per person, the financial impact of international birdwatching can be substantial.

There are about 760 bird species in Ghana, classified into forest, savannah or terrestrial and water birds. Enquiries have revealed that though most of the forest and savannah birds are indigenous, yet they are not endemic to Ghana. There is also still uncertainty as to whether all the various species of birds found in the West African sub-region as well as Ghana truly belong to these places [3]. Birds are very visible and integral part of the ecosystem occupies many trophic levels in a food chain ranging from consumers to predators. Since early works by [14] and [15] concerning habitat selection in birds, much research has led to the conclusion that configuration of vegetation is of prime importance [16]. [7] summarized the present viewpoint by stating that vegetation structure is ecologically important to birds in many ways, such as providing display perches, shelter and nest sites, and suitable foraging areas. This in turn may lead to many beneficial results; including increased number of offspring produced and decreased competition among species [17].

Furthermore, they do add enjoyment to our lives because of their distinctive colors, showy display also distinctive songs and calls. Conserving and managing birds will therefore result in wise use of some of the most sensitive, fragile and ecologically rich habitats in the world [7]. Birdwatching is the most promising branch of ecotourism because birdwatchers comprise a large and increasing pool of educated and wealthy individuals who desire to observe birds in their native habitats and whose activities have relatively low environmental impact, [2]. Among various kinds of ecotourism, birdwatching has the highest potential to contribute to local communities, educate locals about the value of biodiversity, and create local and national incentives for successful protection and preservation of natural areas [8]. The governments of less-developed nations, local and international NGOs, and birdwatching companies should give priority to birdwatching promotion and education. These organizations should also strive to increase the contribution of birdwatching to rural communities and local grass-root organizations since birdwatching has a significant potential to generate income through the protection and promotion of natural areas.

Human activities that affects birds and their habitats are pervasive and increasing. Effects of these activities are manifested at all ecological scales, from short-term changes in the behavior of an individual animal through local extirpations and global extinctions [18]; [19]. Consequently, understanding the effects of humans on birds and their population, as well as devising strategies to ameliorate these effects, is an increasing challenge for resource managers. Virtually all human activities can affect birds' populations either positively or negatively. Those activities that are likely to have adverse effects can be 
divided into those that function primarily by altering the physical environment in a relatively permanent way and those that cause change to an animal's behavior. Activities that alter the physical environment change the amount of habitat for a species. Examples include activities that directly alter the structure and composition of the landscape, such as agroforestry, agriculture, livestock grazing, settlement, open land and unregulated off-road vehicle use. In general, these are land use practices that alter the trajectory of ecological succession, including changing the dominate plant communities and the abiotic features of the area.

The Study on diversity, distribution and abundance of birds with respect to different habitat types is important since it will provide a better understanding on the birds diversity, distribution and abundance within natural and human occupied habitats, also to create more awareness on the positive impacts birds have on the environment, serves as the leverage for other researchers to work more on birds in relation to the seasons we have in Ghana, and finally a platform for promoting bird watching in the country.

\subsection{Problem Statement}

Kakum National Park is among the 7 national park managed by the Wildlife Division under the Forestry Commission of Ghana. The mandate of the division is to conserve wildlife in Ghana in general and manage wildlife protected areas in particular within representative ecological zones of the country. Kakum National is the most visited National park in Ghana. Facilities and recreational activities such as: Bird Watching, Children's Park, Camping, Hiking, and the Canopy Walkway have been the main reasons why tourist visit the park. Out of the 760 species of birds found in Ghana, Kakum alone possesses 266 species including eight species of global conservation concern, therefore this makes Kakum an important bird area recognized by the Bird Life International. Birds play some important roles in the ecosystem, they are bio indicator of healthy ecosystem, insectivores' species and raptors regulate disease vectors, scavenger birds, biomass cycling, and seed dispersal.

However, increase in global demand for food in recent decades, alongside increasing human population, agricultural development and certain factors has transformed vast areas into homogeneous agricultural land to enhance productivity, this has disproportionally affected the availability of some species of birds.

As a result, this study has come up with a comprehensive information on bird abundance that covers the entire landscape from settlement areas, farmlands to the natural forests. Information on the avifauna of the Kakum landscape will help to fill in the gaps and update the already existing information on birds in Kakum, highlight the factors affecting bird's abundance, help reaching sound decision on matters pertaining to conservation of biological diversity of the area Kakum Conservation Area (KCA).

\subsection{Significance}

Birds have enormous positive effects on the environment. Birds have influence on the economy of a nation, on the environment, social and the cultural life of the surrounding settlement such as: serving as a link between bird diversity and local income, education and employment of local guides, contribution to ornithological knowledge and generate fund for the government to assist community in their challenges through bird watching income [3].

This study will provide suggestions to help reduce the anthropogenic activities that has caused degradation of bird habitat, and also help promote bird watching in Kakum National Park. Results in this study will enhance our understanding of birds and their vital ecological importance in the ecosystem, help achieve conservation goals, tourism promotion and rural livelihoods. Moreover, the results of the study will provide a broad overview of bird's diversity and distribution in relation with habitat features, and also increase income generated by the park, it will help improve conservational policies for biodiversity. Perhaps, it will also form the basis for future researchers who wish to work on birds and also be a valuable source of information to Kakum National Park, Tourism Industry, Ghana Tourism Authority and even outsiders who wants to know more about birds in Kakum National Park. 


\subsection{Objectives}

The main objective of the project is to conduct birds survey in Kakum Conservation Area and its catchment areas.

The specific objectives are to:

- To identify bird species diversity in an undisturbed and disturbed areas around Kakum National Park.

- To compare birds' species composition and distribution in the two habitat types.

- To identify the effects of anthropogenic activities in the habitat types on bird abundance.

\section{Study Area}

\subsection{Description of the Study Area}

Kakum Conservation Area consist of a National Park and a Resource Reserve. Kakum National Park and Assin Attandanso Game Production Reserve lie in the Upper Guinea forest zone in southern Ghana [3]. Together they comprise a $360 \mathrm{~km}^{2}$ of moist evergreen forest and also seasonal dry semi-deciduous forest, it receives an annual rainfall of $1,380 \mathrm{~mm}$ [3]. Kakum National Park is located in the TwifoHemang-Lower Denkyira District in the Central Region of Ghana. It is located just 33 kilometers from Cape Coast in the Central Region of Ghana. It lies within longitude 1 5" East and $12^{\prime \prime}$ West and on latitude 5 39" North and 5 20" South. A study by [3] revealed that Kakum National Park has more than five rivers and the main river is being called Kakum River which supplies fresh water to Cape Coast Metropolis and 133 other towns, communities and villages. The river was named after the cry of a Mona monkey (Cercopithicos mona) "Kiakum"" Kiakum".

The Kakum Forest, was named after Kakum River whose headwaters lie within the park's boundaries, was originally set aside as a forest reserve in 1925. Although there is a disagreement as to the exact date of their demarcation, they have been 'reserved' since the 1930s [20]. Logging, which began in the 1930s, was intensified in the 1950s and continued until 1989 when the Central Region Administration suspended all logging. These two forest reserves are now managed as Kakum Conservation Area by the Wildlife Division of the Forestry Commission. The Kakum Conservation Area was legally gazette as a National Park and Resource Reserve in 1992 under the Wildlife Reserves Regulations (LI 1525) under the administrative Jurisdiction of the Wildlife Department. The park was officially opened to the general public in 1994 [3]. The park is surrounded by fifty-two (52) fringe communities and 400 hamlets.

Recreational activities that can be undertaken in the park include; nature walk, bird watching, camp site and tree house, canopy walkway and butterfly watching. It is inhabited by a diverse plant and animal species. It serves as a home for more than five different kinds of globally endangered species of mammals which include forest Elephants, (Loxodonta africana) Bongo, (Tragelaphus eurycerus) Diana Monkey, (Cercopithecus diana) Black and White Colobus Monkey (Colobus guereza) and Yellow Buck Duiker, (Cephalophus silvicultor) [9].

It serves as a habitat for over 266 different species of birds and over 100 species of mammals, reptiles, amphibians and 600 different species of butterflies. One of the butterfly species found in Kakum is (Diopetes kakumi) which was originally discovered in the conservation area. The uniqueness of this park lies in the fact that it was established at the initiative of the local people and not by the State Department of Wildlife who are responsible for wildlife preservation in Ghana [3]. It is also the only park in Africa with a canopy walkway, which is 350 meters $(1,150 \mathrm{ft}$.) long and connects seven tree tops which provide access to the forest. The canopy walkway was designed by Dr. Illar Muul a Canadian ecologist and was constructed by two Canadians namely; Tom Ainsworth and John Keelson and was assisted by six Ghanaians who were also expert in tree climbing. The construction took place in the year 1994 and took six months before it completion. The maximum weight the walkway can take is eight tons ( 8 tons), which is equivalent to eight thousand kilogram $(8000 \mathrm{~kg})$, this weight is said to be the weight of two forest elephant. 


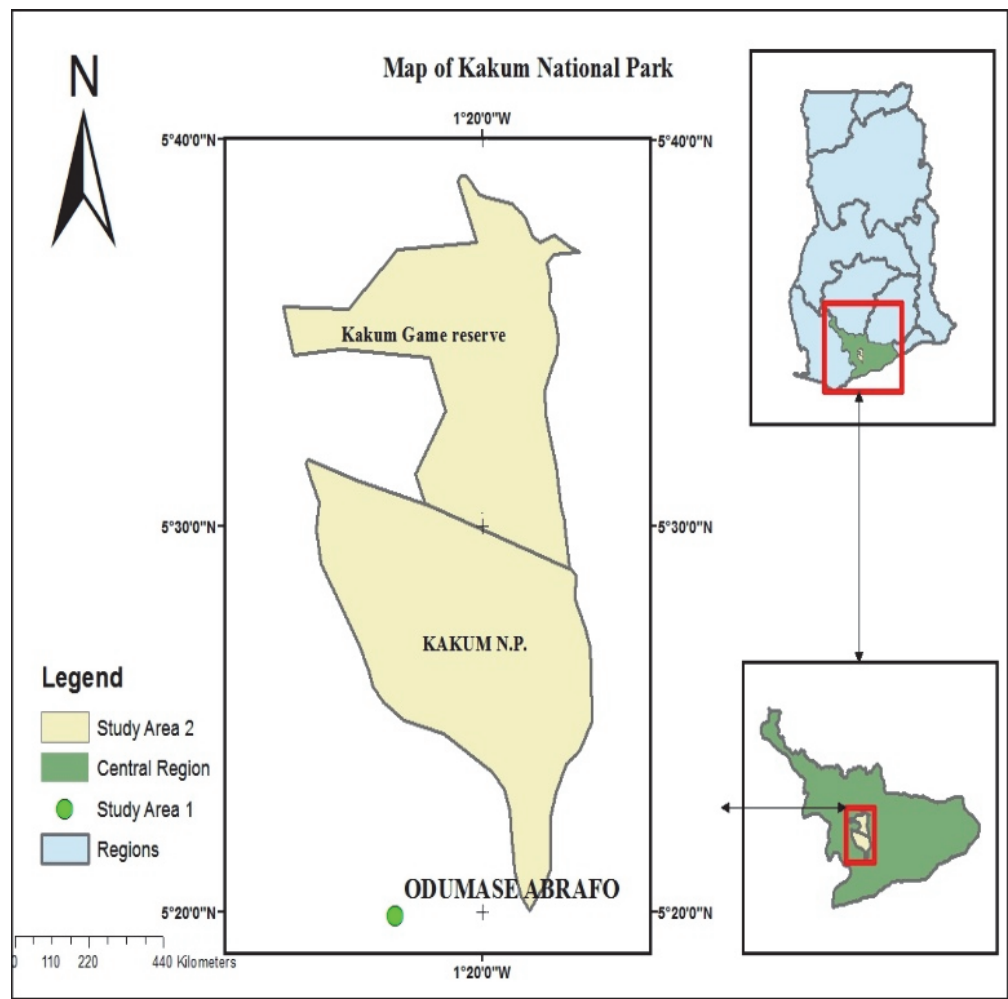

Figure 1. Map of the study area

\subsection{Method}

The study was conducted in Kakum National Park in the Central Region of Ghana between March to May, 2018 using Point count method in both Undisturbed area (Natural forest) and Disturbed area (Farmlands and Settlement) [21].

Opportunistic observations were made along the points to establish any form of disturbance present. The form of the disturbance was placed into two categories; vegetation clearing and invasive plants. Vegetation clearing involved activities such as, vegetation cutting, vegetation burning, cultivation, settlement and livestock grazing. On the other hand, bird watching on the canopy walkway and visitor's presence were also seen as disturbances to birds found in the natural forest. Therefore, a forest area was defined as an area with a high density of trees more than 50\% and close canopy characterized by over stores layers (shrub layer, herb layer and above layer); and a woodland as an area of low density trees with open canopy of $20 \%$. The point count method is most suitable method for counting birds in such uneven terrain (steepness), and dense undergrowth in which detection of birds using other techniques may be difficult [21].

\subsection{Data Collection}

Using point count method to monitor bird population in On-reserve and Off-reserve, the field work was carried out in the morning between 6:00 am to 10:00 am (most birds are active at that time) for five (5) stations at regular interval of thirty (30) minutes each, upon reaching a point, 1-2 minutes were provided for the birds to settle in case of any disturbances, for a total distance of 350 meters long, to avoid double counting on an individual at each station, stations were at least 70 meters away from one another, birds were counted and recorded by observation and vocalization within $15 \mathrm{~m}$ radius.

Play back call technique involve playing recorded sounds of the target bird species. It's mainly used to elicit response from secretive birds which on hearing the calls will call back or move in search of the other bird. Flying birds were excluded in both sites because, their particular locations were difficult to determine. Date, bird species, number, were recorded. Birds were identified to the species level, feeding 
guild of identified species and their taxonomic groups were properly categorized based on Helm field guide by [22], field binoculars (Nikon $10 \times 42$ ) was used to assist in the observation and identification of the bird species. The Garmin GPS device was used to take the coordinate and location of the stations. This study was limited to diurnal birds only due to lack of special equipment to detect nocturnal birds.

\subsection{Data Analysis}

where, $n i=$ the number of individuals in the $i^{\text {th }}$ species,

Relative abundance: $=\frac{\boldsymbol{n i}}{\boldsymbol{N}} \times 100$

$N=$ total number of individual of species recorded during the survey.

$$
\text { Population Density }=\frac{\text { Number of bird }}{\text { total distance }(m)}
$$

The diversity of birds' recorded was calculated using Shannon-Wiener diversity index (H)

The Shannon Index is given by the following formula,

$$
\text { Shannon index }(\mathrm{H})=-\sum \mathrm{Pi}(\mathrm{InPi})
$$

where;

$\mathrm{Pi}=$ the relative abundance of each species, calculated as the proportion of individuals of a given species to the total number of individuals in the community. $\frac{\boldsymbol{n} \boldsymbol{i}}{\boldsymbol{N}}$

The value of the index ranges from 1.5 (low species richness) to 5.0 (high species and richness). [21].

Species evenness was evaluated using Evenness Index $(E)$ as follows: $E=\frac{\boldsymbol{H}}{\boldsymbol{H m a x}}$, where E$=$ Evenness Index, $\mathrm{H}=$ Shannon-Wiener diversity index and Hmax = InS-natural logarithm of the total number of species.

Sørensen similarity index $(\mathrm{S})$ was used to measure species similarity of habitat types. It is designed to equal to 1 in case of complete similarity between two habitats and 0 if species of two habitat types are dissimilar

Sørensen similarity index (S) was computed as:

$$
\mathrm{S}=\frac{2 C}{(\boldsymbol{A}+\boldsymbol{B})}
$$

where: $\mathrm{A}$ and $\mathrm{B}$ are number of species in habitat $\mathrm{A}$ and $\mathrm{B}, \mathrm{C}$ is the number of species common to both habitats A and B. Difference in bird abundance between habitats types was tested using the Mann Whitney U-test whereby habitats were treated as an independent variable and abundance as a dependent variable [9].

\section{Results}

\subsection{Abundance}

During the study a total of 456 bird were recorded, 218 individuals, consisting of 28 families and 80 species were recorded in the undisturbed area and 238 individuals, consisting of 32 families and 71 species were recorded in the disturbed area (Appendix). Nine (9) species occurred in both habitats: Little greenbul (Andropadus virens), Common bulbul (Pycnonotus barbatus), Olive sunbird (Cyanomitra olivacea), Green crombec (Sylvietta virens) African harrier hawk (Polyboroides typus), Red-rumped thinkerbird (Pogoniulus atroflavus), Speckled thinkerbird (Pogoniulus scolopaceus), African pied hornbill (Tockus fasciatus), Tambourine dove (Turtur tympanistria). When the Mann-Whitney U-test was used to evaluate the differences of the abundance and the species richness of birds between the variance of all the species population, it was found that the number of birds in the Off-Reserve differed significantly from the On-Reserve as $\mathrm{p}<0.05(\mathrm{U}=3578, \mathrm{p}=0.0001)$. This rejects the hypothesis that the abundance of birds' species at different sites is the same. 


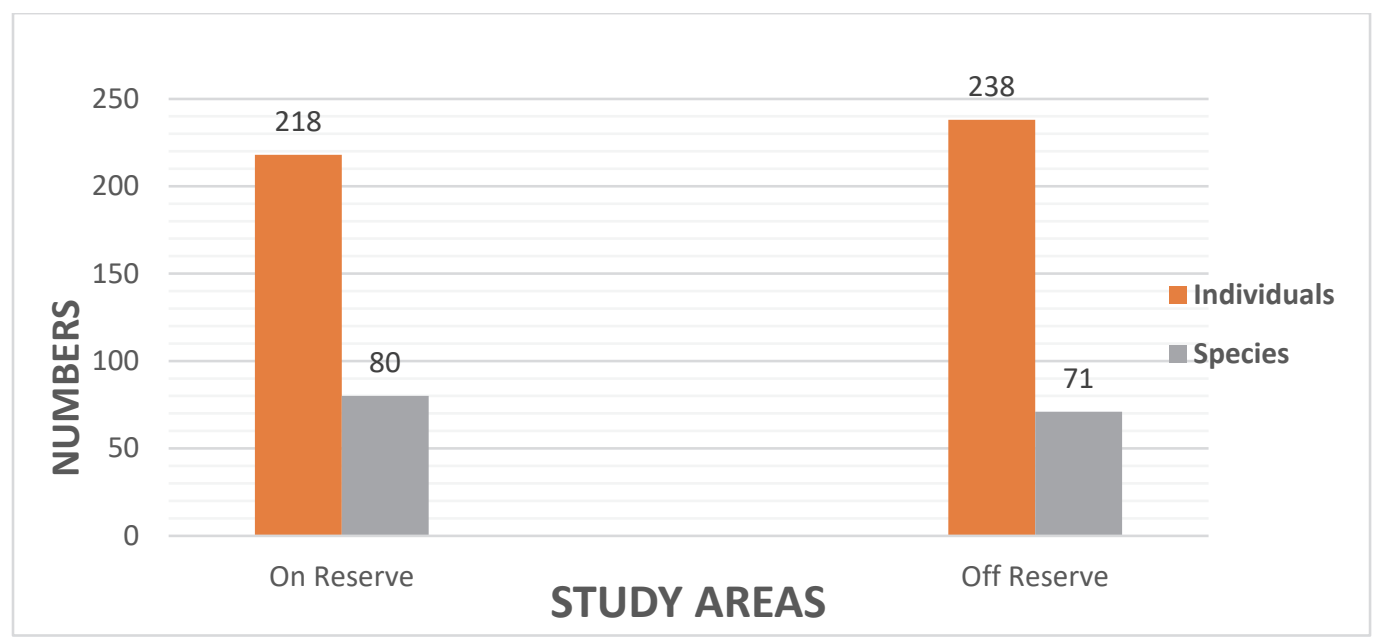

Figure 2. Abundance of birds in both sites

Table 1. Bird density in the study area

\begin{tabular}{lllll}
\hline Study Area & Density $\left(\right.$ birds $/ \mathbf{m}^{2}$ ) & Size & Proportion (\%) & Standard Error \\
\hline On-Reserve & 0.6 & 218 & 48 & 10.5 \\
Off-Reserve & 0.7 & 238 & 52 & 8.4 \\
\hline
\end{tabular}

The most abundance species in the On-Reserve was the Western beared greenbul (Criniger barbatus) $(\mathrm{RA} \%=11.01)$, Icterine greenbul (Phyllastrephus icterinus) (RA\% = 4.13), Common bulbul (Pycnonotus barbatus) (RA\% = 3.67), African green pigeon (Treron calvus) (RA\% = 3.66), Tiny sunbird (Cinnyris minullus) (RA\% = 3.21), Rufous-crowned eremomela (Eremomela badiceps) $(\mathrm{RA} \%=$ 2.70), Swamp palm bulbul (Thescelocichla leucopleura) (RA\% $=2.29$ ), Naked-faced barbet (Gymnobucco calvus) (RA\% $=2.29)$.

The following species were abundant in the Off-Reserve Village weaver (Ploceus cucullatus) $(\mathrm{RA} \%=$ 8.40), Common bulbul (Pycnonotus barbatus) (RA\% $=5.04$ ), Lesser-striped swallow (Cercropis abyssinica) (RA\% = 5.04), Little swift (Apus affinis) (RA\%=4.20), African pied crow (Corvus albus) $(\mathrm{RA} \%=3.36)$, Black and white manikins (Spermestes bicolor) (RA\% = 2.94), Bronze manikin (Spermestes cucullatus) $(\mathrm{RA} \%=2.52)$. (RA= Relative Abundance).

\subsection{Diversity of Birds in Their Families}

The most abundant family in the undisturbed area is the "Pycnonotidae", followed by "Nectariniidae", "Estrildidae", "Capitonidae" and "Columbidae", these families were relatively abundant in the natural forest, whereas the "Platystriridae", "Indicataridae", "Glaredidae", "Psitadidae", and "Coraciidae" had the lowest abundant together with least number of species. The families "Nectariniidae", "Pycnonotidae", and "Capitonidae", had the highest number of species and are considered the most diverse families. 


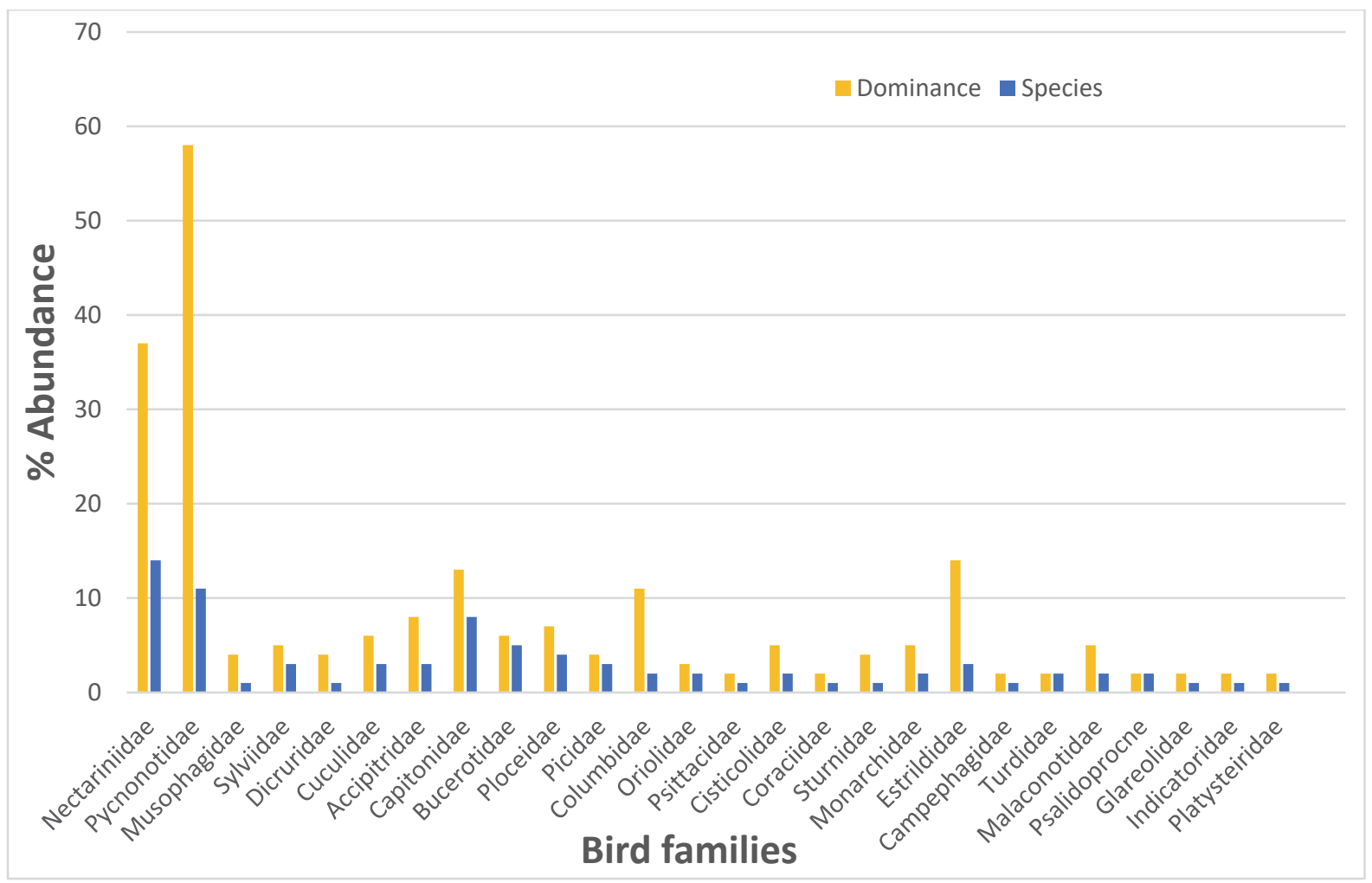

Figure 3. Relative abundance of birds' families found in the undisturbed area

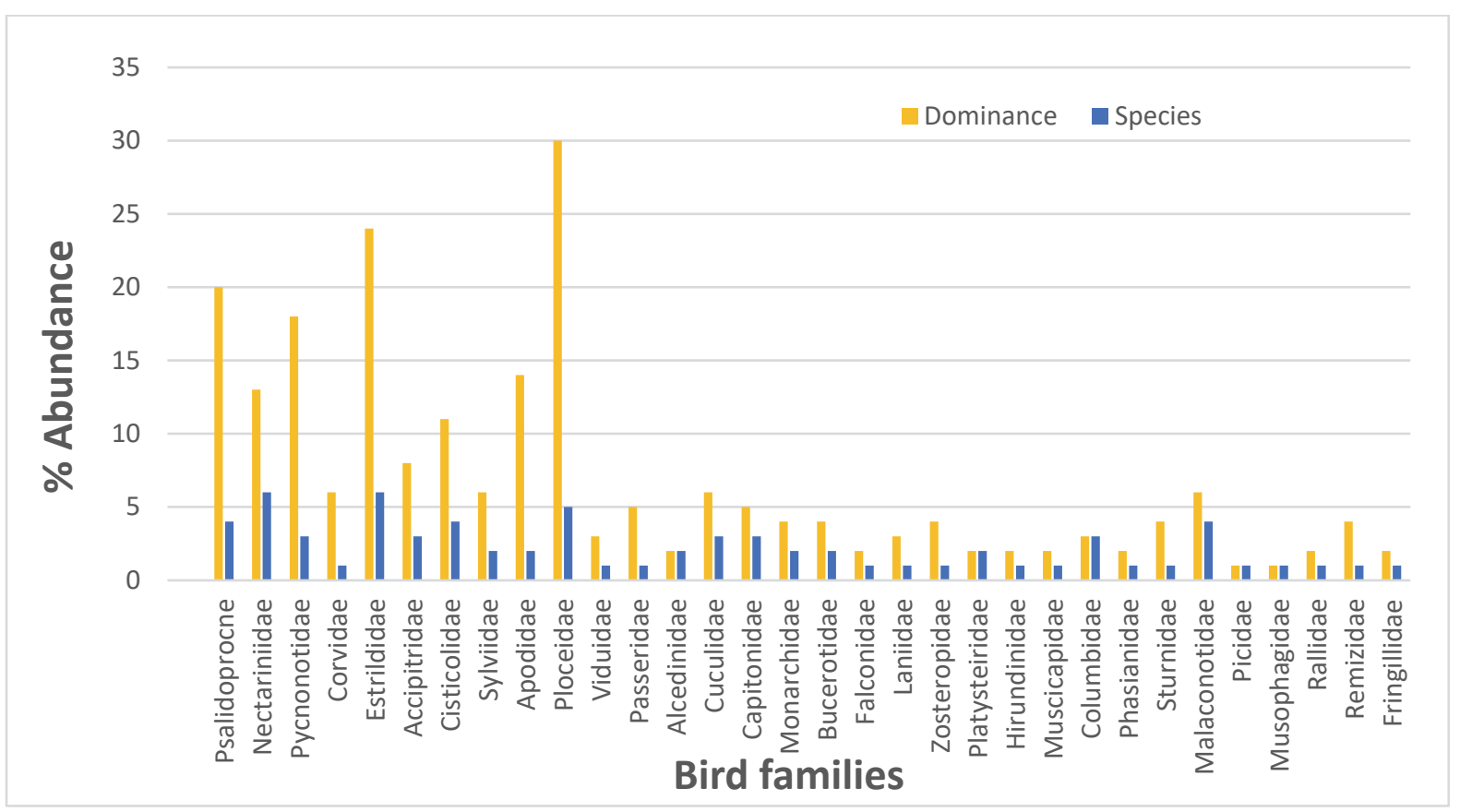

Figure 4. Relative Abundance of birds' families found in the disturbed area

In the disturbed area the most abundant families are the "Ploceididae", "Estrildidae", and "Psalidoprocne", "Pycnonotidae", "Apodidae", "Nectariniidae", "Cisticolidae" whereas the following families had the least abundant and species numbers in the area; "Picidae", "Musophagidae", 
"Platysteiridae". The families, Estrildidae", "Nectariniidae", and "Ploceididae", had the highest number of species and are considered the most diverse families.

\subsection{Feeding Guild Categories}

A feeding guild is a group of species that exploits similar food resources in a habitat, and its characterization is usually based on the type of food being consumed, which in turn determines the feeding behavior of the availability of food resources. Foraging guild can be useful way to compare changes between species rich communities because their functional organization can be investigated even if no species are shared [7]. The foraging behavior of birds' species based on the Point count method were grouped into seven (7) trophic structures to determine the feeding behaviors of different bird species and the food resources of the areas. Surprisingly, there was no significant difference in their feeding guild among the bird species $(\mathrm{t}=0.167, \mathrm{df}=6$, and $\mathrm{P}=0.878$ at $\alpha=0.05)$.

\subsubsection{Feeding guild in the On-Reserve (undisturbed area)}

The results show that, the Frugivore/Insectivore (34.4\%), Nectarivore/Insectivore (20.6\%), Insectivore $(20.2 \%)$ and Frugivore (13.8\%) were the abundant feeding guild, Granivore/Insectivores (7.8\%), Omnivores (1.4\%), Carnivores (1.8\%) which comprise of raptors were the rarest feeding guild in the area.

\subsubsection{Feeding guild in the Off-Reserve (disturbed area)}

The results show that, the Frugivore/Insectivores (35.5\%), Granivore/Insectivores (35.1\%), Insectivore (11.3\%) were the abundant feeding guild in the area, Nectarivore/ Insectivores $(7.4 \%)$, Carnivores (5.6\%), Frugivore $(3.5 \%)$ and the Omnivores $(1.7 \%)$ were the less abundant feeding guild in the disturbed area.

\subsection{Diversity and Evenness}

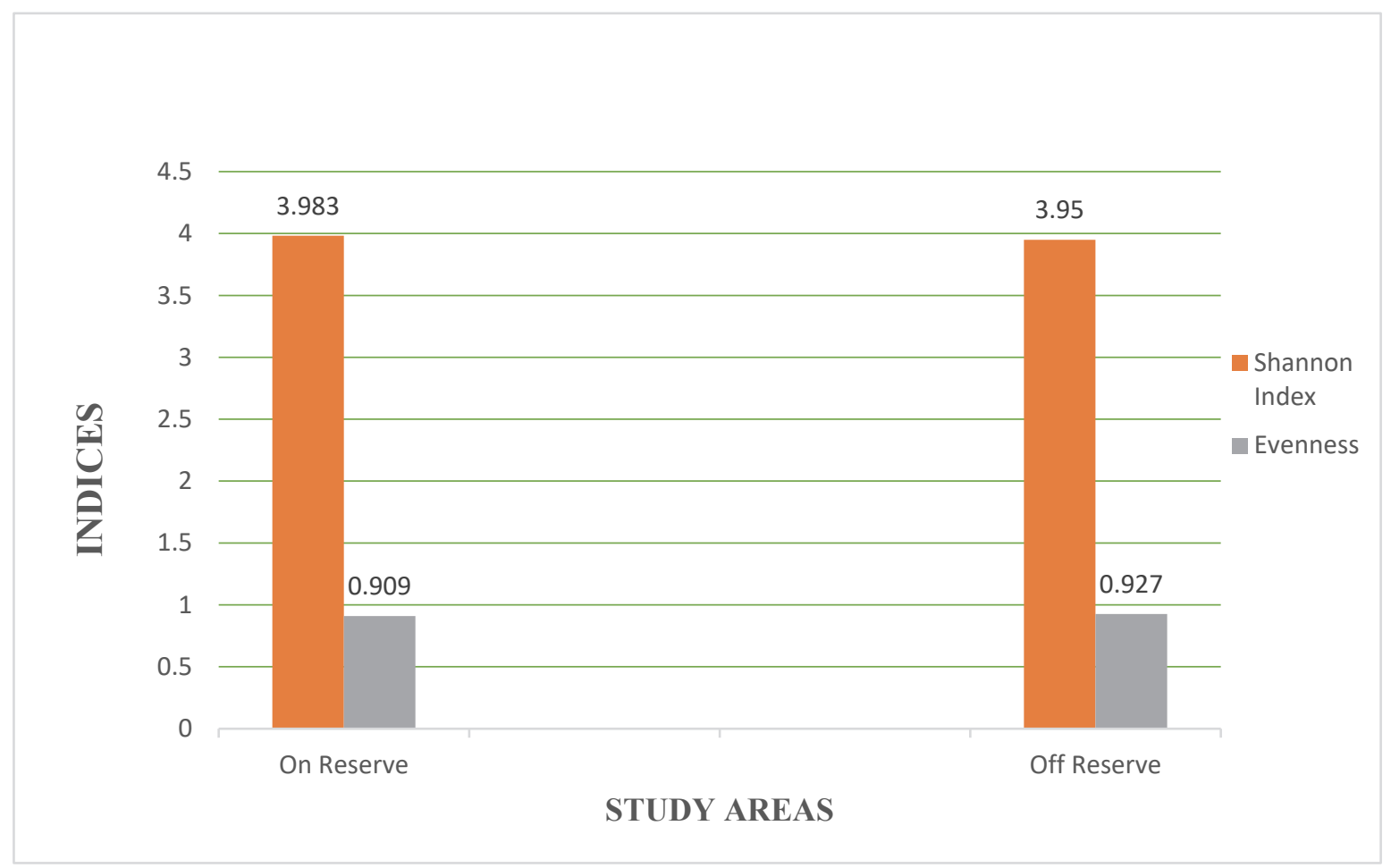

Figure 5. The species diversity and evenness of birds at both sites

The Shannon-Weiner diversity index of bird species surveyed in the undisturbed area was 3.983 and evenness of 0.909 (at a confidence limit of 95\%) and in the disturbed area, Shannon index was 3.950 and 
evenness of 0.927 (at a confidence limit of 95\%), this has been graphically shown in the diagram below. Diversity t-test was conducted to test the hypothesis that diversity of bird within any two habitat types are the same or not. Results indicated that diversity of birds between the two habitat are with no significant difference, that is, they are the same $(t=0.099, \mathrm{df}=1$ and $\mathrm{P}=0.933$ at $\alpha=0.05)$. This shows that there was not much difference in diversity between the On-Reserve and the Off-Reserve bird species. It also shows that almost the same number of species were restricted to both habitats. It was observed that 80 species were recorded in the On-Reserve and 71 species were also recorded in the OffReserve, species richness was therefore higher in the On-Reserve than the Off-Reserve.

Sorensen similarity index of bird species was calculated to support the hypotheses that bird species are the same or not in both sites, similarity between the sites was 0.12 , the results showed that the similarities between bird species in the sites was relatively low (' 1 ' complete similarity; ' 0 ' complete dissimilarity) and this may be due to the fact that these habitats are not closer to each other.

\subsection{Distribution}

The study recorded 456 individual birds, from 60 families and 151 species, distributed within the two habitats (On-Reserve and Off-Reserve) (Appendix). One of the most important biological barriers is the non-availability of food [7]. Many animal species have limited distributions that are associated with the distribution of plants or other animals on which they feed [7]. Species with very narrow food preferences (stenophagus species) are much more likely to be limited in their distribution by their food than are species with very broad food preferences (euryphagus species).

For example, seed eaters (Rock pigeons) will have wider distributional ranges than the fruit eaters (Green pigeons). Similarly flesh/carrion eaters (Birds of prey) have wider ranges compare to the fish eaters (e.g. Osprey). Omnivorous (e.g. generally are cosmopolitan in distribution and are found almost everywhere. Among the 60 families surveyed, Netariniidae (Sunbirds), Cuculidae (Coucal), Accipitridae (Flesh Consumers), and Ploceidae (Weavers) were relatively well distributed across the two habitat than the rest. (Appendix)

\section{Discussion}

The results, (Figure 2) indicated that there was a higher bird abundance and densities in areas with highly induced human activities and decreased towards woodland and in forest areas. These results concur with the findings by [23] and [24] who concluded that human-disturbed areas provide heterogeneous habitats which attract human tolerant bird species. Higher abundance per species count and density in the Off-Reserve could have had been contributed by few species that can coexist with humans such as Bronze Manikins (Spermestes cucullatus), Common Bulbul (Pycnonotus barbatus) and House Sparrow (Passer domesticus). Other studies elsewhere in human settlements [25]; [26] also found similar result and concluded that higher abundance in the settlement were triggered by habitat heterogeneity such as buildings, trees and gardens created by man.

It was observed that farmlands had the higher abundance of birds, this could be associated with the greater openness in the habitat which supports plants that provides food and cover for different bird species [7]; [26]; [27]. On-Reserve (Forest) habitat had a lower individuals recorded, the least number could be due to forest degradation which affect forest birds and could also be triggered by the temporal and spatial movements of bird species following specific species requirement such as nesting sites and breeding site for them to survive [28]. Decreased cover for escape from enemies and shelter, food supply and breeding sites increases competition within and between species hence the decrease in number can be reflected. The understory vegetation beneath plantations such as cocoa, rubber and oil palm by several authors in fact promote bird richness and abundance. This was supported by this study where bird abundance in Off-Reserve habitat was found to be higher than the On-Reserve habitat. The understory could be providing food source, refuge and breeding sites for birds and other species. In spite of the fact that plant species abundance and structure was greatest in the natural forest bird abundance was lower compared to farmland. This habitat had most species restricted to it because of farming activities. The understory of these plantation is suggested as a significance source of food and shelter for species thus promoting biodiversity in these areas [29]; [30]. Conservation on farmlands/plantations is 
therefore necessary since that is where most birds are also found. Rare species in all habitat should be conserved since its extinction from the study area will also led to extinction of some bird species from the area. [31].

Virtually all human activities can affect wildlife populations either positively or negatively. Those activities that are likely to have adverse effects can be divided into those that function primarily by altering the physical environment in a relatively permanent way and those that cause changes to an animal's behavior. Activities that alter the physical environment change the amount or the suitability of habitat for a species. Widespread and large-scale examples include activities that directly alter the structure and composition of the landscape, such agriculture, forestry, livestock grazing, and unregulated off-road vehicle use. (Plates)

The forms of vegetation disturbance identified at the disturbed area during the study were; vegetation clearing and invasion by terrestrial plants. Vegetation clearing was the most common form of disturbance in the area.

Vegetation clearing was mainly done through burning of vegetation, cutting of trees, livestock grazing and cultivation in the area. Vegetation burning was one of most common forms of vegetation clearing observed throughout the study period and it occurred in patches in parts of the reserve. Besides vegetation burning, vegetation cutting was also a common form of vegetation disturbance in the reserve. Several patches of cut vegetation were observed in different parts of the reserve. (Plates 1 \& 2)

Vegetation was cleared in a part of the reserve to create room for cultivation and plantation which was mainly carried out along the edges of the reserve. The main crops planted were, cassava, palm trees and maize. Some of the plantation practice at the place are Rubber plantation, Cocoa plantation and Palm oil plantation. (Plate 5)

Vegetation clearing through livestock grazing was also common in the disturbed area. A total of 40 sheep could be seen grazing along the edges of the area, where the ground was dry and firm during the period of December, 2017 to May 2018. These animals seemed to forage closer to the edge of the area during the dry season than the wet season. Livestock grazing resulted into trampling and removal of vegetation, thereby slowing down regeneration. Large concentration of grazing animals poses harmful effects on plants due to selectivity and overgrazing. [6].

The quality of the birds' habitat was described in terms of the structural characteristics of height and density of vegetation. Forms of disturbances such as clearing of vegetation, affected the habitat quality (height and density) directly for example, by reducing the vegetation cover. Vegetation height and density are important characteristics for breeding birds, especially during breeding time. Therefore, disturbance effects on vegetation density and height negatively affected diversity and richness of birds' species. (Figures $2 \& 5$ ) Majority of the birds recorded in both habitats were perching. This happened because most birds in the study area are attracted to some tree, herb and shrub species. This shows the need to conserve these tree, herb and shrub species.

The expectation of many birdwatchers are not always beneficial and the excessive zeal of some birdwatchers to see or photograph certain species may have harmful consequences. A review of 27 studies on the effects of wildlife observation and photography on birds reported negative effects on birds in 19 of the studies, even though most of these may be due to photography rather than birdwatching [32]. Unfortunately, there are few well-designed, long-term studies of bird disturbances by birdwatchers and other nature observers and the data are from fewer than 100, mostly temperate species, obtained mainly during the breeding period [33]. Well-designed, long-term studies are sorely needed, especially in the tropics where there has been almost no published bird disturbance research and still maintain. [33]. (Plate 6).

Impacts of disturbance are complex, with responses differing between species, between individuals of the same species, and even between different periods for the same individuals. Majority of bird studies indicated that most birds are more sensitive to disturbances during the breeding period. Human presence around birds' nests increased nest abandonment and eggs loss due to nest predators. [34]. Many birdwatchers play calls of secretive species to lure them out of their hiding places and, during the breeding period, this may stress birds, as well as leave nests exposed to predators. There have been no studies on the effects of tapes on birds and this should be a research priority of bird disturbance researchers. Even outside the breeding period, birdwatchers should minimize flushing of birds, since this has high physiological costs for many species and can be fatal to birds during times of food shortage. 
Larger and more specialized species, birds of prey, birds in groups, and birds far from vegetation cover tend to be flushed more easily [33].

The foraging habitat of the identified birds were assessed to explore the variation in birds' composition among habitat types; according to [35], variation in vegetation structure affects the distribution of bird foraging guilds. Frugivorous/Insectivorous were the most dominant group in both habitats. This guild was mostly composed of species from the family Pycnonotidae such as Western bearded greenbul (Criniger barbatus) from the forest. According to [7], insectivores are often found to be most species rich and abundant in tropical forest, which support the findings of [36]. The availability of a variety of food sources for both adults and young and safe habitat for nesting and roosting in and around forest habitat are important for the occurrence and abundance of insectivorous species. On the one hand, insectivores in farmlands provide benefits to farms by mitigating the abundance of insect pests in farmland and settlement habitats, which enhances the conservation value of farms for birds and other wildlife [37].

The abundance and richness of fruiting plants is important and associated with the diversity of frugivorous bird species and foraging behaviors in certain habitat types [38], the capture rate of frugivores in forests is generally greater during periods when fruits are abundant, the presence of species belonging to the family Stunidae, Oriolidae, Pycnonotidae is a perfect indicator of forest regeneration in semi-degraded/disturbed habitat such farmlands and settlement. The tolerance of frugivores species to disturbed landscapes is important during initial forest succession and restoration in tropical regions [39]. According to [7], in order to increase bird biodiversity, existing green spaces must be conserved, fruit trees planted.

Nectarivores were least abundant in the disturbed area and the presence of more Nectarivore in the forest may be explained by the availability of flowering resources and the seasonality of flowering, (Figure 3). [7] emphasized that the structure and composition of bird community changes in space and time with the availability of food resources and variation tends to most visible among bird species that feed on patchy and temporary food resources, such as nectar and fruit. [31] found fewer species of Nectarivore in disturbed landscapes(farmland/settlement) as the intensity of land modification increased. [40] added that the abundance and diversity of Nectarivore are correlated with increase in nectar availability. [41] noted that Nectarivore are difficult to observe because of their small size and are likely underestimated relative to other guilds. Furthermore, according to [42], higher bird species was found in the forest than in the disturbed area.

The families Estrildidae and Ploceidae recorded a higher number of species in the disturbed landscape (Figure 4) probably because the conditions needed by their members were available in the study area. Example, Village Weaver (Ploceus cucullatus) belonging to Ploceidae is the most abundant species in the study area due to the abundance of their food (Seed-eating birds). The Common Bulbul (Pycnonotus barbatus) belonging to Pycnonotidae are also among the abundant species and are mostly found on farmlands due to the availability of food (Seeds) [43]; [7].

They were commonly observed on the ground and in grassy habitat were they would pick grains from plant sources such as maize and grasses. This shows that these 2 families are the most diverse in the study area (Figure 4). Most plants completed their reproductive processes between the early months of the year. Also, harvesting of crops on farmlands started in January and there was much left over foods on farmlands for birds to feed on. Granivores are considered as pests by local farmers in the area [44]. [45] concluded that fields left fallow after harvest support high densities of many species of granivorous birds, and they emphasized that variation in the abundance and availability of weeds affects the diversity of granivorous species. Furthermore, the presence of a high diversity of granivores in a habitat indicated habitat disturbances [44].

The species diversity index and evenness of bird species during the entire period revealed that the OnReserve (forest habitat) had the highest species diversity of 3.98 (Figure 5) this is because of the availability of multiple and variety of alternative food sources for the birds. Most of the large area of the Kakum forest is inaccessible to people, contributing to favorable conditions for breeding, feeding and nesting sites. The Off-Reserve is exposed to the local people for cultivation and cutting of the vegetation, and this causes birds depending on these sites for feeding, nesting and breeding being affected in diversity. In natural habitats where the intervention of humans is less and minimum, the diversity as well as the evenness of species is higher than the fragmented ones where intensive farming is carried out [46]. Differences in feeding habits and habitats could also increase diversity, evenness and species 
richness. The highest diversity observed in On-Reserve was more likely because of well sufficient vegetation cover than in the Off-Reserve (settlement and farmland) which has been affected by land use changes [47].

The highest species diversity indicates a complex community in which a high degree of species interaction is possible contrary to higher dominance observed in Off-Reserve (settlement and farmland), which implies that few species predominate the habitats. Though farmland showed less diversity, higher dominance was due to persistence of native and generalist species like a large number of Cattle egret (Bubulcus ibis), Common Bulbul (Pycnonotus barbatus), Village Weaver (Ploceus cucullatus). [23]; [25]. On the other hand, the higher evenness in the forest is supported by continuation of vegetation which reduces the impact of predation to adult birds, young and eggs. The result agreed with many research which conclude that forest is the main habitat which harbors large bird species diversity [27]; [48]; [49]; [50]. As vegetation changes along environmental gradients, certain bird species may appear, increase or decrease in number and disappear as the habitat changes [51].

The studied habitat types recorded 151 bird species which call attention for conservation. According to [26] and [52] the distribution patterns of bird species normally follow the spatial; structure of the environment and habitat requirement of the bird species. This correspond with this study whereby habitat specificity and generalization were observed. For example, Red-rumped thinkerbird (Pogoniulus atroflavus), Speckled thinkerbird (Pogoniulus scolopaceus), African pied hornbill (Tockus fasciatus), were recorded in both habitat type. On the contrary, African pied crow (Corvus albus), Sooty boubou (Laniarius leucorhyncus), Yellow bill kite (Milvus migrans parasitus), Woodland kingfisher (Halcyon senegalensis), Bronze manikin (Spermestes cucullatus), Bar-breasted firefinches (Lagonosticta rufopicta) were recorded in the disturbed area (settlement, farmlands).

Although human settlement areas have mixtures of built habitat and green patches, bird species have managed to exist and survive in this complex habitat. This is explained by the availability of ecological requirement for the species offered by a mixture of an environment with settlement and garden patches [24]. This highlights that while species may be similar between habitats, still there is a difference in requirement hence it is important to conserve a mosaic of natural habitats.

\section{Conclusions}

Bird species diversity was higher in the area with less human activities, i.e. forest than the farmland and settlement, the higher diversity suggests higher ecological stability compared to human disturbed habitat, yet settlement and farmland are imperative part of the ecosystem that harbor large numbers of birds compared to forest, the study provided information about the diversity and structure of bird communities in different habitat around Kakum National Park, and the result suggests that differences in resource availability between habitat such as breeding sites, nesting materials, cover, food and water restrict some species to certain habitat type while allowing others to be widely distributed, the study also concluded that any human activity that alters the habitat structure impact birds abundance, diversity and their distributions.

\subsection{Recommendations}

In order to improve bird diversity in human occupied environment gardening and tree planting should be encouraged. This will enhance bird species diversity such that human settlement and farmland will no longer be viewed as a lost habitat for wildlife, but rather a habitat that with proper management, has the potential to support diverse bird communities.

Since communities lack awareness that birds are important part of ecosystem as environmental health indicator, pollinators and pest controller, the department of Natural Resource, Land and Environment in the municipality has to provide conservation education to the communities so that the contribution of birds in the ecosystem can be realized.

Cooperation among different stakeholders i.e. ecologists, land surveyors, municipal council, social scientists, environmentalists, communities and bird watcher groups is required to ensure birds are conserved. A conservation group such as WD (Wildlife Division of Ghana) should initiate the cooperation. 
It was observed during field visit that the communities do not know the biological resource and value that made Kakum National Park area popular. This suggests that research findings are not communicated back to the society. As result, societies have no knowledge on the importance of the area for this and coming generations.

Birdwatching activity should be minimized around nests and young, especially around nesting colonies. Since birds are highly sensitive to noise and the number of people [14], groups should be kept small, preferably under 10 people. Rigorous training, certification, and regulation of guides, especially in lessdeveloped countries, by governments and by birdwatching companies, are integral to educating tourists and minimizing disturbance to birds [30].

Birds are less sensitive if they are visually shielded from observers [43], so birdwatchers should make use of inconspicuous clothing blinds, telescopes, vegetation and other ways to minimize being seen by birds (Larson 1995) to limiting disturbance. Minimizing bird disturbance and flushing will improve the quality of birdwatching and may increase bird abundance and species richness [33].

Further studies should be done to compare the population of bird species both in the dry season and the raining season, to determine the appropriate time for bird watching.

\subsection{Limitations}

The bird numbers might have been altered or affected by the method used. By walking on a transect and point counting, certain birds might be recorded more than once.

Since the study was carried in the day time only, some of the birds in the study areas might be nocturnal and such birds were not recorded.

Acknowledgements. The authors are grateful to the Management of Kakum National Park, especially Ms. Ernestina Annie and Mr. Enock Amasa Ashie.

\section{References}

1. Gray, M. A, Baldauf, S. L, Mayhew, P.J \& Hill, J. K (2007): The response of avian feeding guilds to tropical forest disturbance 21(1):133-141

2. Lack, D. 1933. Habitat selection in birds with special reference to the effects of afforestation on the Breckland avifauna. Jour. Animal Ecol., vol. 2, pp. 239-262.

3. Smith-Asante E. (2001). Independent Newspaper. Accra

4. Kellert, S. R. (1985). Birdwatching in American Society. Leisure Sciences, 7(3\}, 343-360.

5. Rajashekara, S \& Venkatesha, M.G (2014). Insectivorous bird communities of diverse agro-ecosystems in the Bengaluru region, India. Journal of Entomology and Zoology Studies 2(5):142-155.

6. Harvey, C. and Gonzalez - Villalobos, J. A. (2007). Agroforestry systems Conserve species -rich but modified assemblages of tropical birds and bats. Biodiversity Conservation 16: 2257 - 2292.

7. Agyei-Ohemeng, J., Adu Bright Yeboah, Asamoa Francis (2019) Ecological status of birds in Sunyani using their foraging habits, Journal of Biodiversity and Environmental Sciences (JBES) ISSN: 2220-6663 (Print) 22223045 (Online) Vol. 14, No. 6, p. 62-69, http://www.innspub.net

8. American Birding Association. (2010). About the ABA publications. Colorado Springs, CO: Author. Retrieved June 28, 2010, from http://www.aba.org/publications/

9. Eagles, P. F. J. (2010b). Personal interview: Ecotourism and bird-watching tourism. Waterloo, Department of Recreation and Leisure Studies, University of Waterloo.

10. Lichstein, J. W., T.R. Simons, and K. E. Franzreb. (2002). Landscape effects on breeding song-bird abundance in managed forests. Ecological Applications 12, 836-857.

11. Butler, J; \& Fenton, G. D. (1987). Bird watchers of Point Pelee National Park, phase one: Bird watchers of Point Pelee National Park, Ontario: Their characteristics and activities, with special consideration to their social and resource impacts. Alberta Naturalist, 17(3), 135- 146.

12. Eagles, P. F., McCool, S. F., \& Haynes, C. D. (2002). Sustainable tourism in protected areas:Guidelines for planning and management: IUCN.

13. Cordell, H. K. and Herbert, N. G. (2002). The popularity of birding is still growing. Birding 34: 54-59. 
14. Loiselle, B. A (1988). Bird abundance and seasonality in a Costa Rican lowland forest canopy. Condor. 90:761-772.

15. Pimm, S. L., G.J. Russell, J. L. Gittleman, \& T. M. Brooks. (1995). The future of biodiversity. Science 269, 347-350 pp.

16. Moreau, R. E. 1934. A contribution to tropical African bird ecology. Jour. Animal Ecol., vol. 3, pp. 41-69.

17. Boateng, I (2009) GIS assessment of coastal vulnerability to climate change and coastal adaptation planning in Vietnam. Journal of coastal Conservation, Vol.1, issue 1, pp25-36.

18. Sandstrom, U.G; Angelstam, P. \& Mikusinski, G. (2005). Ecological diversity of birds in relation to the structure of urban green space. Landscape Urban Plan 77:39-53.

19. Chapin, F. S., Zavaleta, E. S., Eviner, V. T., Naylor, R.L., Vitousek, P. M., Reynolds, H. L., Hooper, D. U., Lavorel, S., Sala, O. E., Hobbie, S. E., Mack, M. C. and Díaz, S. (2000). Consequences of changing biodiversity. Nature 405: 234-242.

20. Eggert, L., Eggert, J., \& Woodruff, D. (2003). Estimating population sizes for elusive animals: the forest elephants of Kakum National Park, Ghana. Molecular ecology, 12(6), 1389-1402.

21. Bideberi, G (2013) Diversity, Distribution and Abundance of avifauna in respect to habitat types: a case study of kilakala and bigwa, morogoro, Tanzania. Sokoine University of Agriculture, Morogoro Tanzania.

22. Borrow, N and Demey, R. (2010). Birds of Ghana. Published by Christopher Helm, London

23. Chace, J. F., \& Walsh, J. J. (2006). Urban effects on native avifauna: A review. Landscape Urban Plan 74:46-69.

24. Shochat, E; Lerman, S \& Fernández-Juricic, E. (2010). Birds in Urban Ecosystems: Population Dynamics, Community Structure, Biodiversity, and Conservation. Urban Ecosystem Ecology 55:75-86.

25. Rodríguez-Estrella, R. (2007). Land use changes affect distributional patterns of desert birds in the Baja California peninsula, Mexico. Diversity and Distribution 13: 877-889.

26. Twerefou, D. K., Ababio, D. K. A., \& Daniel, A. (2012). An economic valuation of the Kakum National Park: An individual travel cost approach. African Journal of Environmental Science and Technology, 6(4), 199207

27. Askins, R. A; Folsom-Okeefon, C. M \& Hardly, M. C. (2012). Effect of vegetation, corridor width and Regional land use on Early Successional Birds on Powerline corridor. Plos one 7 (2): 1-10

28. Shankar Raman, T. R. (2001) Effect of Slash-and-Burn Shifting Cultivation on Rainforest Birds in Mizoram, North-east India. Conservation Biology, 15; 685-698.

29. Howe, H. F. \& Smallwood, J. (1982). Ecology of seed dispersal. Ann. Rev. Ecol. Syst.13: 201-228.

30. Johnson, M.D, Kellermann, J.L, Stercho, A.M (2010). Pest reduction services by birds in shade and sun coffee in Jamaica. Animal Conservation 13(2):140-147.

31. Alexander, B. B \& Kwame, I. P (2009). Diversity and Distribution of birds in the owabi wildlife sanctuary and its catchment area: Impact of land use change. Kwame Nkrumah University of Science and Technology. Department of theoretical and applied biology.

32. Boyle, S.A. \& Samson, F.B. (1985). Effects of nonconsumptive recreation on wildlife: a review. Wildlife Society Bulletin 13:110-116.

33. Grez, A. A., Moreno, P. \& Elgueta, M. (2003). Coleopteros (insecta Coleoptera) epigeos associados al bosque maulino y plantaciores de pino aledanas. Rev. Chil Entomology 29: 9-18.

34. Isaacs, J. C. (2000). The limited potential of ecotourism to contribute to wildlife conservation. Wildlife Society Bulletin 28: 61-69.

35. Rana, S. V. S. (2005). Essentials of Ecology and Environmental Science $2^{\text {nd }}$ Ed. Prentice - Hall of India Private Ltd., New Delhi.

36. Sekercioglu, C. H (2002) Impacts of birdwatching on human and avian communities. Environmental Conservation 29 (3): 282-289, Center for Conservation Biology, Department of Biological Sciences, Stanford University, Stanford, CA 94305-5020, USA

37. Lee, P. \& Rotenberry, J. T. (2005). Relationships between bird species in forested habitats of Eastern North America. Journal of Biogeography. 32: 1139-1150.

38. Pearman, P. B. (2002). The scale of community structure: habitat variation and avian guilds in tropical forest understory. Ecological Monographs 72: 19-39.

39. Corlett, R. T. (1998) Frugivory and seed dispersal by vertebrated in the oriental region. Biological reviews of the Cambridge Philosophical Society 73:413-448.

40. Cox, P. A. and Elmqvist, T. (2000). Pollinator extinction in the Pacific islands. Conservation Biology.14: 1237-1239. 
41. Moorcroft, D; Whttingham, M. J; Bradbury, R. B \& Wilson, J. D (2002). The selection of stubble fields by wintering granivorous birds reflects vegetation cover and food abundance. Journal of Applied Ecology. 39(3): 535-547.

42. Moegenburg, S. M \& Levey, D. J (2003). Do frugivores respond to fruit harvest? An experimental study of short-term responses. Ecology. 84(10):2600-2612

43. Li, S, Zou, F, Zhang, Q \& Sheldon, F. H (2013). Species richness and guild composition in rubber plantations compared to secondary forest on Hainan Island, China. Agroforestry Systems. 87(5):1117-1128.

44. Honey, M. (1999). Ecotourism and Sustainable Development: Who Owns Paradise? Washington DC, USA: Island Press.

45. Pennington, D. N \& Blair, R. B. (2011). Habitat selection of breeding riparian birds in an urban environment: Untangling the relative importance of biophysical element and spatial scale. Diversity and Distribution 17:506 - 518.

46. Sekercioglu, C. H. (2002c). Impacts of birdwatching on human and avian communities. Environ. Conservation. 29: 282-289.

47. Giannecchini, J. (1993) Ecotourism: New partners, new relationships. Conservation Biology 7: 429-432.

48. Campbell, M \& John, M. (2012). Habitat Fragmentation and Birds [faculty.ncwc.edu/mbrooks/pif/.../fragmentation fact sheet. Htm] site visited on $24^{\text {th }}$ April 2012.

49. Azeria, E.T; Sanmartı 'n, I; Stefan A; Carlson, A \& Burgess, A. (2007). Biogeographic patterns of the East African coastal forest vertebrate fauna. Biodiversity Conservation 16 (4): 883-912.

50. Burgess, N.D; Doggart. N and Lovett, J. (2002). The Uluguru Mountains of Eastern Tanzania: the effect of forest loss on biodiversity. Oryx 36: 140-152.

51. MacArthur, R. H., MacArthur, and J. W. \& Freer, J. (1962) On Bird Species Diversity: II. Prediction of Bird Census from Habitat Measurements. The American Naturalist, 96; 167-174. Macthur, R. H., and Macthur, J. W. (1961) On Bird

52. Buckley, H.L and. Freckleton R. P. (2010). Understanding the role of species dynamics in abundanceoccupancy relationships. Journal of Ecology 98: 645-658. 


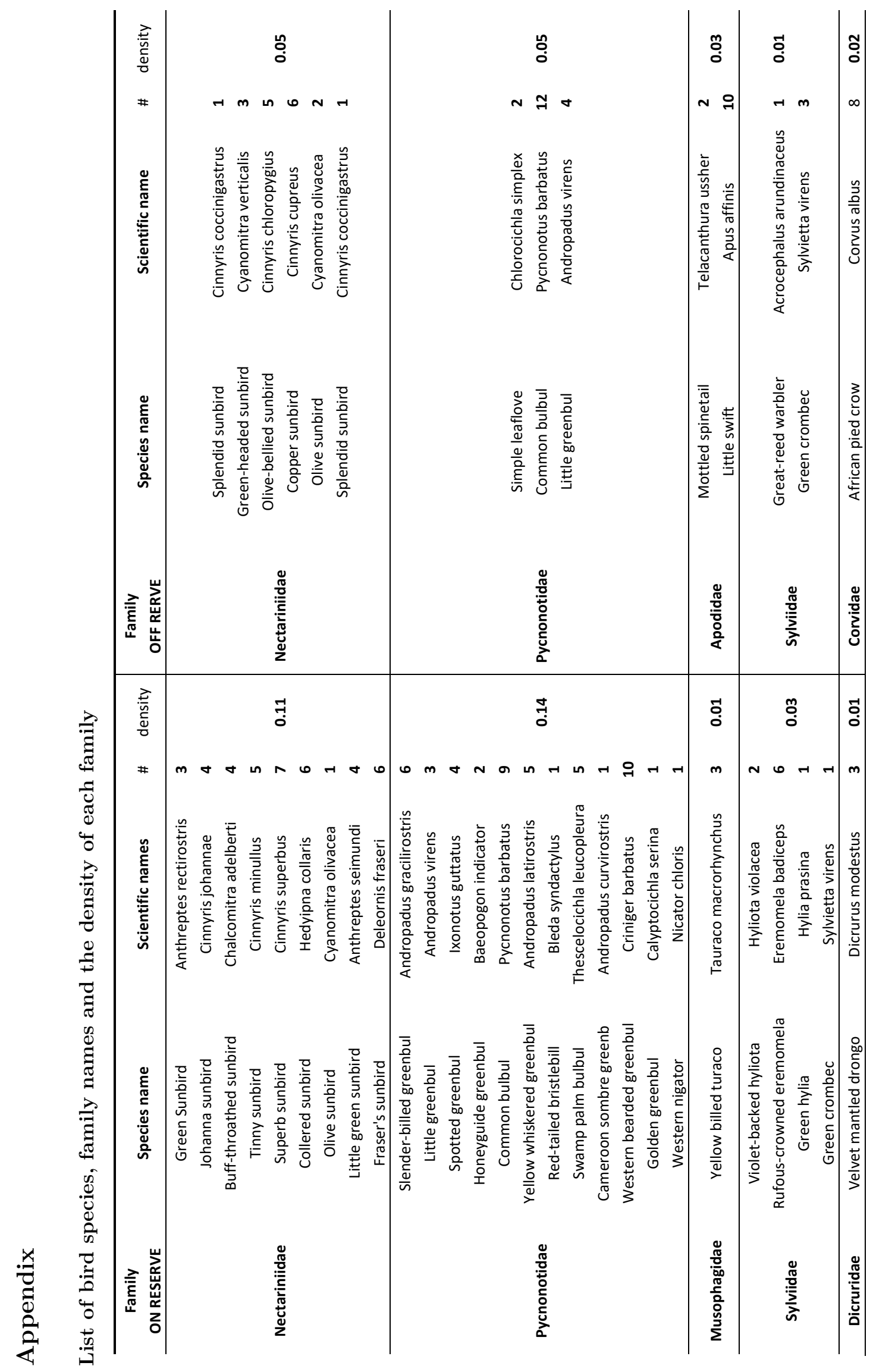




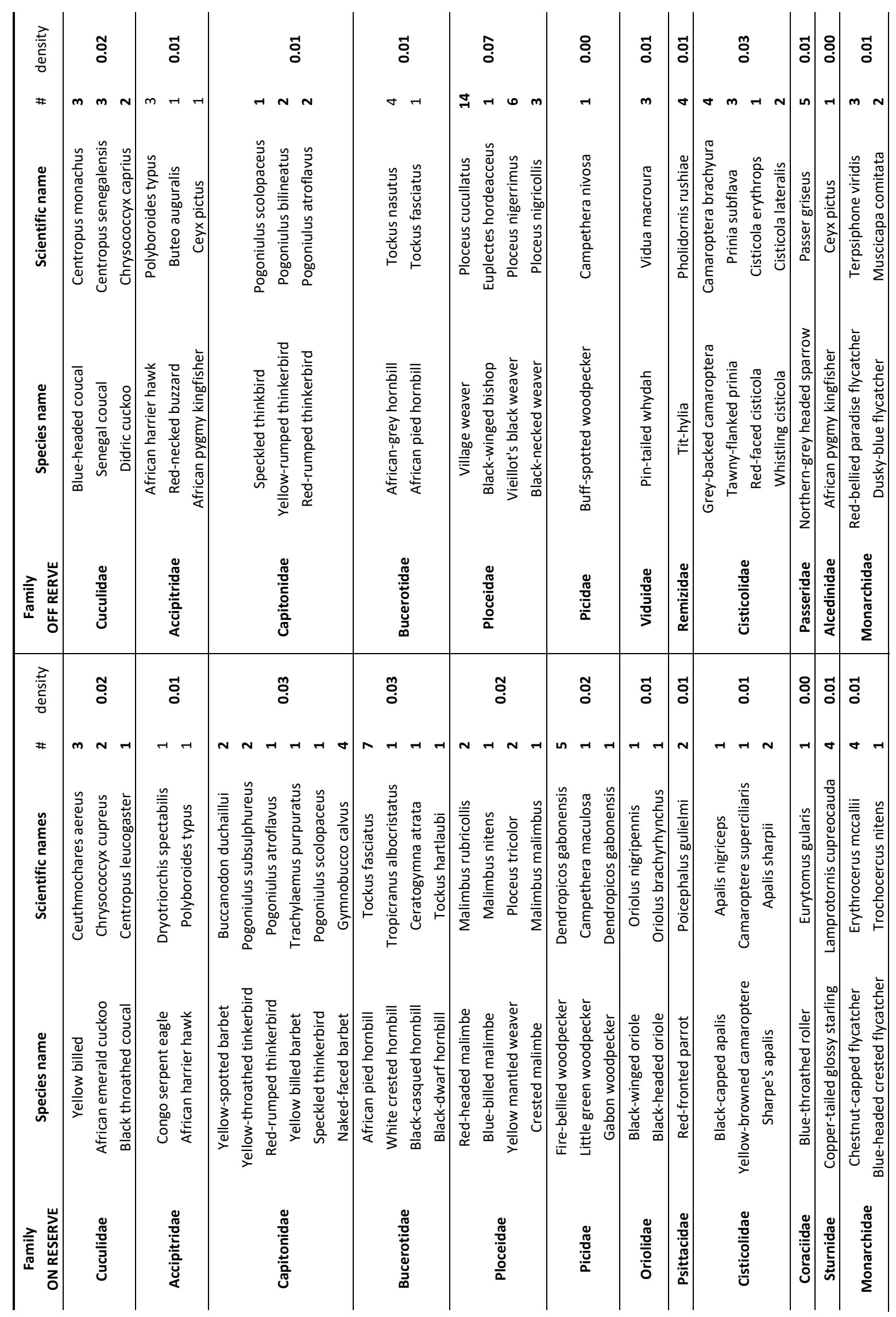




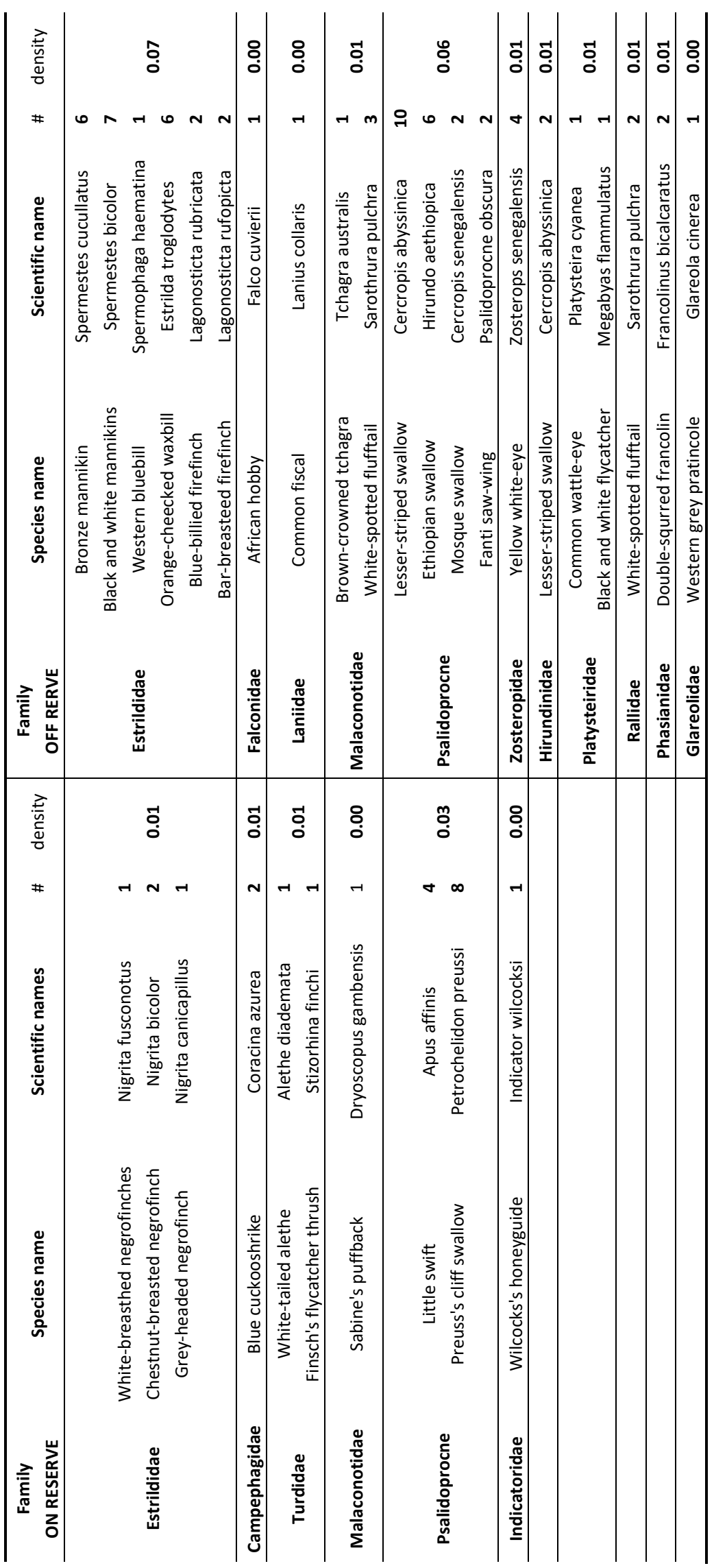


Plates: Anthropogenic activities encounterd during the survey

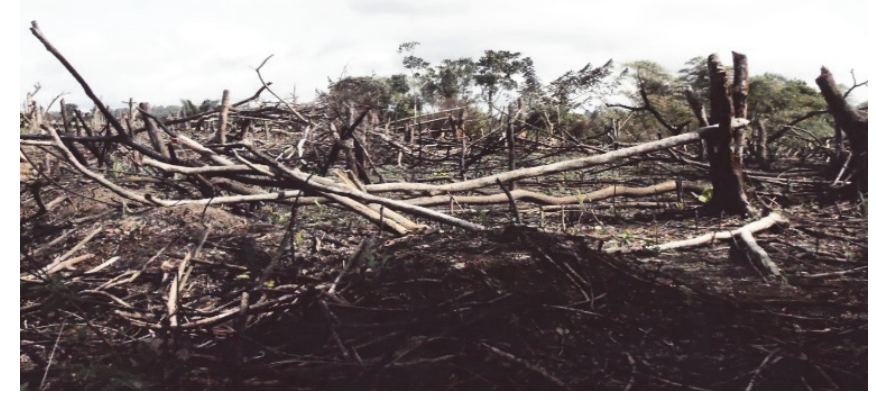

Plate 1. Picture of burnt vegetation

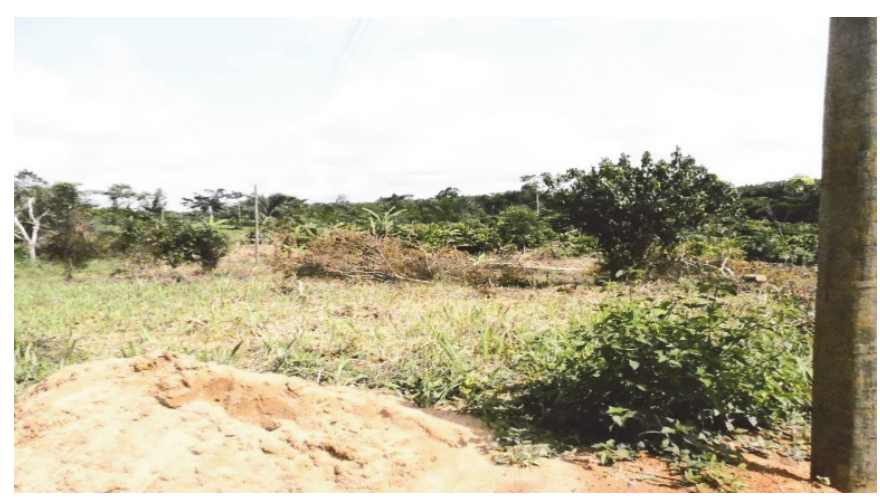

Plate 2. Picture of cleared vegetation

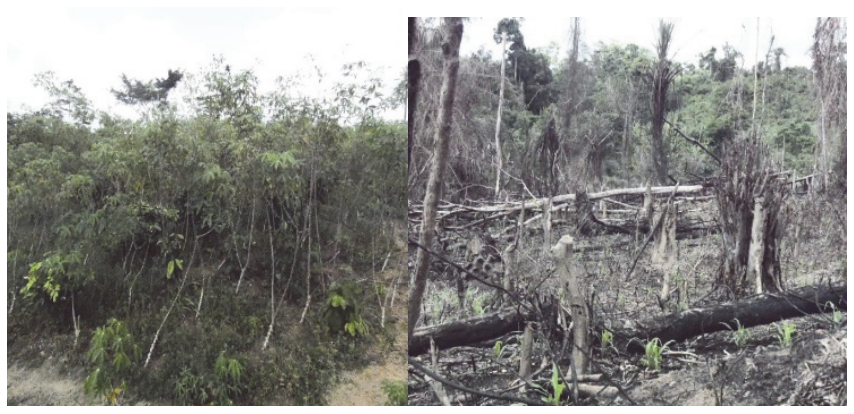

Plate 3. Cultivation along the edges of the disturbed area (corn and cassava). 


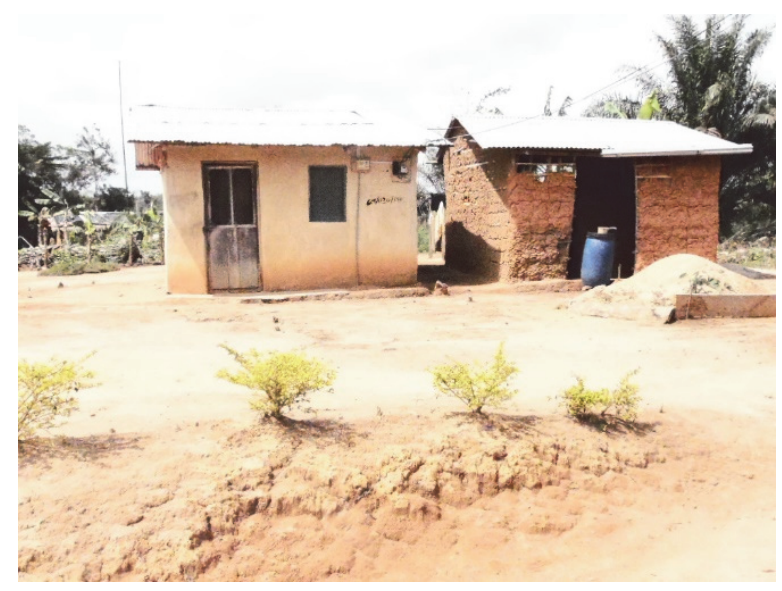

Plate 4. Settlement in the Disturbed area

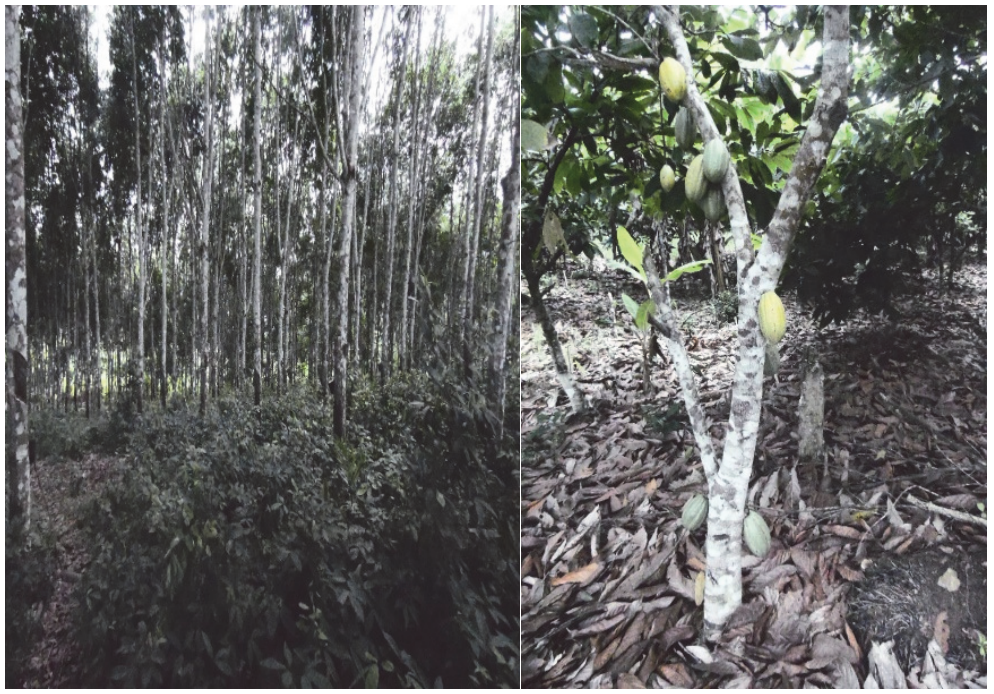

Plate 5. Plantation (Rubber and Cocoa)

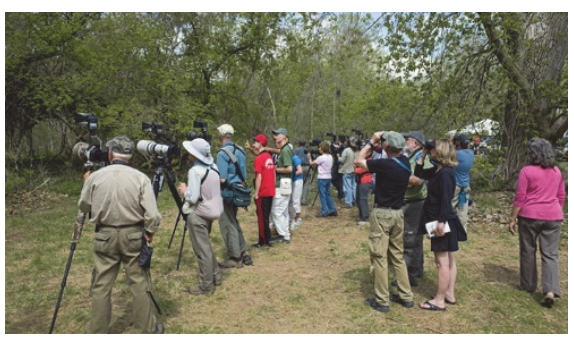

Plate 6. Group of bird watchers 